\title{
Satellite Projects by Indian Students
}

\author{
Palani Murugan \\ IRS \& SSS Programme Management and Systems Group \\ UR Rao Satellite Centre, ISRO, \\ Bangalore-17
}

\begin{abstract}
Indian Space Research Organization (ISRO) has launched more than hundred satellites for various applications like communication, Earth observation, Astronomy, Navigation, Lunar studies and interplanetary mission from its inception. Addition to its own programmes, it induced Indian student community to make satellites by guiding, providing facilities to test the subsystems and satellites. It also launches these satellites by Polar Satellite Launch Vehicle (PSLV). The student satellite projects provide the design, fabrication, assembly and testing experience of electrical and mechanical systems to university students. It provides experience in project management, budget, schedule and mission planning \& operation also. Indian students have launched more than nine satellites so far and some more are under development. Due to this inspiration many Universities/Colleges had flown their satellites through balloons for testing their capabilities. Some students launched their satellites through other space agencies also. This paper presents the salient features of these satellites and technologies used in Indian Student satellites.
\end{abstract}

Keywords: Student satellites, Nano satellites, university satellites, Miniaturisation

\section{INTRODUCTION}

The artificial satellite is a system which mainly goes around the Earth with a specific purpose. It is a multidisciplinary system which can be divided into two main parts based on their functions as payloads and main frame.

Payloads are the instruments or sensors which are directly related to the applications. In the case of Remote sensing satellites, they are cameras/imaging systems, synthetic aperture radars (SAR), scatterometer etc. and in communication satellites they are receivers and transmitters. Some scientific purpose satellites carry instruments to measure the electron contents, gamma ray detectors. X-ray monitors, ultra violet detectors etc.,

The main frame some times called as bus which carries the Payload. It can be broadly divided into electrical and mechanical systems. Electrical subsystems are power system, communication system, data handling digital systems and attitude $\&$ orbit control system. The power system generates power from solar radiation in sunlit, stores it in battery for the requirement of eclipse duration operation and distribute the power among different systems. The communication system is to receive the command from the ground stations and transmit various information like temperature, pressure, power consumptions consumption of different systems and attitude and orbit information of the satellites to the ground station. Addition to this it transmits the high volume data collected by payload instruments to the ground. The data handling digital system collects the telemetry information from different systems, format them and transmit to communication system[1]. It also collects the commands from communication systems and distribute to relevant system. Addition to this, the data handling system collect data from payload instruments, compress, encode and send to communication system. The Attitude and orbit control system consists of various sensors and actuators. It measures the attitude and orbit information from sensors and activates the actuators for correction if required.

The spacecraft mechanical systems are structure, thermal control systems (TCS) and mechanisms. The structural system is the skeleton of the satellite, mainly made up of Aluminum alloys and Carbon Fiber Reinforced plastic (CFRP) materials. It provides space to mount the electrical and other mechanical systems. The structure is designed to provide sufficient stiffness to maintain the look angles of the payloads and attitude sensors. The Thermal control system provide suitable thermal environment to the electrical and other mechanical systems for their better functionality. As size of some systems like solar panels and antennas violate the heat shield volume of the launch vehicle. They are to be kept folded during launch and deployed after reaching orbit. For this purpose, some mechanisms are designed and employed. Orbit raising and attitude correction are done by propulsion system.

Many satellites are using chemical propulsion for its high thrust and simple design.

The combination of these mechanical and electrical systems is called as main frame and to support payloads. Each system has interface with other system and all work together to achieve a common goal. The data handling and Attitude and orbit control systems utilize embedded software extensively. The ground systems for satellite tracking and payload data processing involve computing and communication systems with tracking antenna.

The satellite design fabrication and testing need multiple field expertise. Satellite projects provide practical experience for students of many disciplines. As the student satellites are launched as piggy back to main operational satellites, the challenge in fabrication of student satellites lies in making satellites with less mass and small in size.

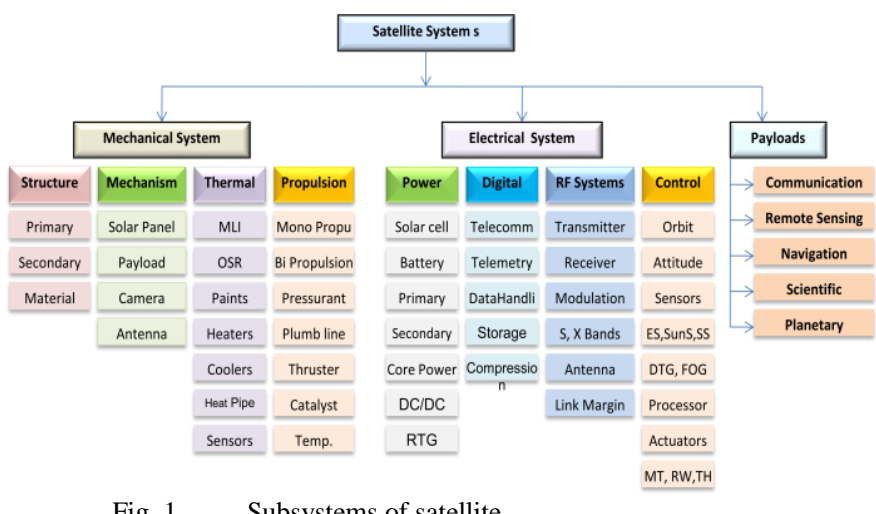

Fig. 1 Subsystems of satellite 


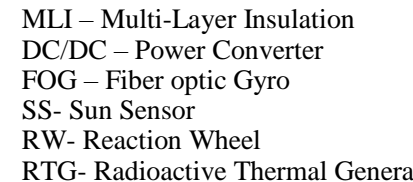

Due to this, student satellites are in mini, cube, pico, nano and micro satellites categories with payloads catering to specific applications. These satellites were designed, fabricated and assembled at corresponding institutions using their funds. ISRO supported in test activities by providing access to its test facilities at UR Rao Satellite centre because the test facilities like thermo vacuum chamber and vibration table are costly. Free launch support was also provided by Polar Satellite Launch vehicle (PSLV). The Fig.-1 provides different subsystems in the satellites and table-1 provides the Names of Indian Student satellites and institutions.

TABLE I. LIST OF INDIAN STUDENT SATELLITES.

\begin{tabular}{|l|l|l|l|l|l|}
\hline S1.N & Satellite Name & Institution & $\begin{array}{c}\text { Launch } \\
\text { Mass }\end{array}$ & $\begin{array}{c}\text { Launch } \\
\text { Vehicl } \\
\text { PSLV }\end{array}$ & Launch Date \\
\hline 1 & ANUSAT & Anna University & 40 & C12 & Apr 20, 2009 \\
\hline 2 & STUDSAT & $\begin{array}{l}\text { Consortium o } \\
\text { colleges }\end{array}$ & $<1$ & C15 & Jul 12, 2010 \\
\hline 3 & JUGNU & IIT Kanpur & $<3$ & C18 & Oct 12, 2011 \\
\hline 4 & SRMSAT & SRM University & 10.9 & C18 & Oct 12, 2011 \\
\hline 5 & SWAYAM & University Pune & 1 & C34 & June 22, 2016 \\
\hline 6 & Sathyabamasat & $\begin{array}{l}\text { Sathyabama } \\
\text { University }\end{array}$ & 1.5 & C34 & June 22, 2016 \\
\hline 7 & PISAT & PES University & 5.25 & C35 & Sept. 26, 2016 \\
\hline 8 & PRATHAM & IIT Bombay & 10 & C35 & Sept. 26, 2016 \\
\hline 9 & NIUSAT & $\begin{array}{l}\text { Nurul Islan } \\
\text { University }\end{array}$ & 15 & C38 & June 23, 2017 \\
\hline 10 & Kalamsat-V2 & Space Kids & 1.26 & C44 & Jan. 24, 2019 \\
\hline 11 & ManipalSAT* & $\begin{array}{l}\text { Manipal } \\
\text { University }\end{array}$ & -- & & \\
\hline 12 & IITMSAT* & IIT Madras & -- & & \\
\hline
\end{tabular}

*To be launched

\section{LAUNCHED SATELLITES}

\section{ANUSAT}

ANna University SATellite (ANUSAT) is the first satellite designed, fabricated and tested by Indian students[2]. It was a cooperative mission of Anna University, Chennai, and Indian Space Research Organization (ISRO)[3]. This satellite was designed and fabricated at Madras Institute of Technology (MIT) campus of Anna University. Most of the sub systems in this satellite are made up of Commercial OffThe-Self (COTS) components.

The Fig. 2 shows the satellite and the Table- 2 provides the salient features of the ANUSAT.

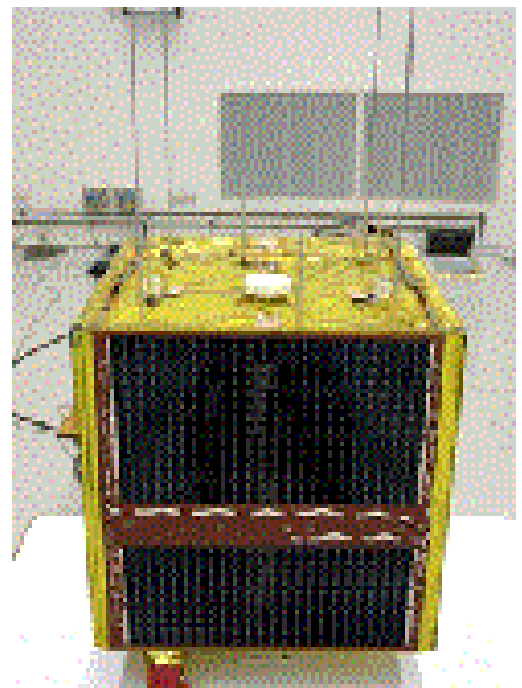

Fig. 2 ANUSAT

Objective

- To encourage the involvement of the Anna University faculty, researchers and students in Space technologies to work as a team.

- To gain hands-on experience a micro-satellite development

\section{Payload}

The ANUSAT Payload was designed to relay the data collected from one place to another place. The payload was designed and fabricated by the Anna University.

TABLE II. SALIENT FEATURES OF ANUSAT

\begin{tabular}{|c|c|c|}
\hline Sl.No & Parameter & Value/ system \\
\hline 1 & Payload & Data relay satellite \\
\hline 2 & Mass(kg) & 38 \\
\hline 3 & Size $\left(\mathrm{mm}^{3}\right)$ & $600 \times 600 \times 600$ \\
\hline 4 & Power $(\mathrm{W})$ & $\begin{array}{l}40 \mathrm{~W} \\
\text { Body mounted GaAs solar } \\
\text { cells. } \\
\text { Battery: Li-ion } 4 \text { x } 4 \\
10 \text { AH. } \\
\text { Bus Volt: } 15.5-16 \mathrm{~V}\end{array}$ \\
\hline 5 & Attitude sensor & $\begin{array}{l}\text { Sun Sensor, } \\
\text { Magnetometer }\end{array}$ \\
\hline 6 & Actuators & Torquers $\left(4.5 \mathrm{AM}^{2}\right)$ \\
\hline 7 & Stabilization & $\begin{array}{l}\text { Spin Stabilized } \\
4 \pm 0.5 \mathrm{RPM}\end{array}$ \\
\hline 8 & Telecommand & $\begin{array}{ll}\text { VHF }(\mathrm{PCM} / \mathrm{FSK} / \mathrm{AM}) ; 100 \\
\mathrm{bits} / \mathrm{sec}, \\
149.2 \mathrm{MHz} .\end{array}$ \\
\hline 9 & Telemetry & $\begin{array}{l}\text { VHF(PCM/FSK/AM); } \\
256 \text { bits/sec., } \\
137.4 \mathrm{MHz},\end{array}$ \\
\hline 10 & $\begin{array}{l}\text { Payload data } \\
\text { Transmission }\end{array}$ & $435 \mathrm{MHz}$ \\
\hline 11 & Orbit & Inclined \\
\hline 12 & Altitude km & 550 \\
\hline 13 & Inclination & $41 \mathrm{deg}$ \\
\hline 14 & Orbital Time & $95.9 \mathrm{~min}$ \\
\hline 15 & Launch Date & 20 April 2009 \\
\hline 16 & Launch Vehicle & PSLV-C12 \\
\hline
\end{tabular}

\section{Ground station}

Independent ground station was set up in MIT campus of Anna University and houses the Telecommand, Transmitter 
and Telemetry Receiver systems. The telemetry Receiver sensitivity is $-110 \mathrm{dBm}$.

\section{STUDSAT}

STUDSAT was the second student satellite of India fabricated by a consortium of colleges from Bangalore and Hyderabad. The consortium was led by NIITE Meenakshi Institute of Technology (NMIT), Bangalore. Other colleges contributed by designing and fabricating different subsystems [4]. The list of colleges involved in this project is as follows.

Bangalore :

- Nitte Meenakshi Institute of Technology (NMIT), - M.S. Ramaiah Institute of Technology (MSRIT),

- Rashtreeya Vidyalaya College of Engineering

- B. M. S. Institute of Technology (BMSIT), Hyderabad

- Chaitanya Bharathi Institute of Technology CBIT),

- Institute of Aeronautical Engineering (IARE),

- Vignan Institute of Technology \& Science (VITS)

The Fig. 3 shows the Studsat- 1 and the Table- 3 provides the salient features of the STUDSAT.

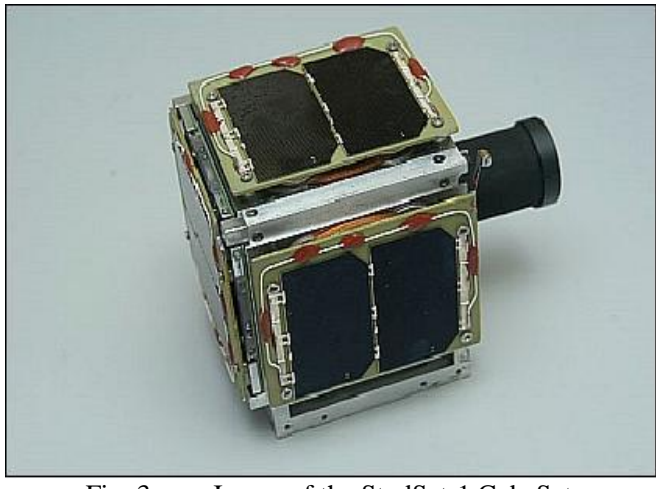

Fig. 3 Image of the StudSat-1 CubeSat

Objective

- To promote space technology in educational institutions.

- To encourage research and development in the design of a miniaturized satellite along with all the experiences, enthusiasm and efforts necessary to bring such a project to completion

\section{Payload}

The STUDSAT payload is a CMOS detector based camera designed to get $90 \mathrm{~m}$ spatial resolution.

TABLE III. SALIENT FEATURES OF STUDSAT

\begin{tabular}{|l|l|l|}
\hline Sl.No & Parameter & Value/systems \\
\hline 1 & Payload & $\begin{array}{l}\text { CMOS Camera with 90m } \\
\text { Resolution }\end{array}$ \\
\hline 2 & Mass $(\mathrm{kg})$ & 1.3 \\
\hline 3 & Size $\left(\mathrm{mm}^{3}\right)$ & $100 \times 100 \times 13.5$ \\
\hline 4 & Power $(\mathrm{W})$ & $\begin{array}{l}33 \mathrm{~W}, \text { Body mounted Si cells, Li } \\
\text { polymer battery 1.24 AH }\end{array}$ \\
\hline 5 & Attitude sensor & $\begin{array}{l}\text { Sun Sensor, } \\
\text { Magnetometer }\end{array}$ \\
\hline 6 & Actuators & $\begin{array}{l}\text { Magnetic Torquers } \\
4.5 \text { AM }\end{array}$ \\
\hline 7 & Stabilization & $\begin{array}{l}\text { Spin Stabilized } \\
4 \pm 0.5 \text { RPM }\end{array}$ \\
\hline
\end{tabular}

\begin{tabular}{|l|l|l|}
\hline Sl.No & Parameter & Value/systems \\
\hline 8 & OBC & $\begin{array}{l}\text { Atmel's ARM based AVR32 } \\
\text { UC3A0512 microcontroller }\end{array}$ \\
\hline 9 & $\begin{array}{l}\text { TCUplink } \\
\text { TM Downlink }\end{array}$ & $\begin{array}{l}145.9 \mathrm{MHz} \\
437 \mathrm{MHz}\end{array}$ \\
\hline 10 & Orbit & $\begin{array}{l}\text { SSPO,635 km Altitude Local Time } \\
\text { on desc Node }\end{array}$ \\
\hline 11 & Altitude $(\mathrm{km})$ & 635 \\
\hline 12 & Local time & 9.30 AM \\
\hline 13 & Period & \\
\hline 14 & Inclination & $87.44^{\circ}$ \\
\hline 15 & Launch Date & $12-$ July-2010 \\
\hline 16 & Launch vehicle & PSLV-C15 \\
\hline 17 & Life Time & Three Months \\
\hline
\end{tabular}

Ground station

An independent ground station called NASTRAC was setup in Nitte Meenakshi Institute of Technology. It received the Telemetry Data and confirmed the satellite is in mission mode.

\section{JUGNU}

Jugnu is a nano satellite designed and fabricated by students of Indian Institute of Technology (IIT) Kanpur[5]. It is a $3 \mathrm{U}$ cubesat aimed to image the earth for Agriculture and disaster monitoring purpose. The Fig. 4 and Table- 4 provides the view and salient features of the STUDSAT.

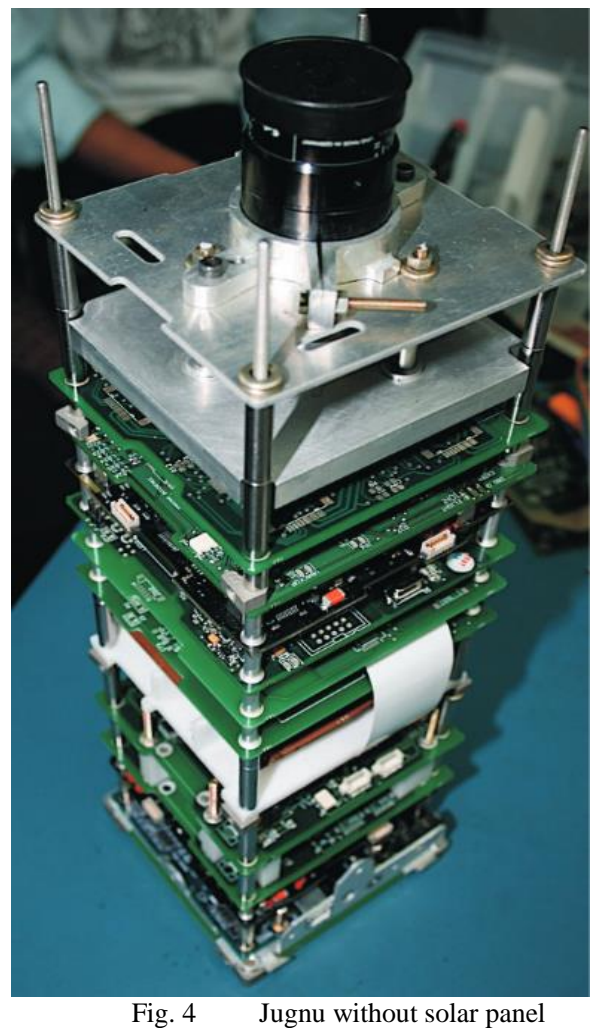

Objective

- To get students involved in research activities based on affordable MEMS technologies

- To test new solutions for the future cost effective space missions

- To set the path for future up gradations and study such validation of concepts

Payload

The JUGNU payload is a near infrared (NIR) camera with $640 \times 480$ pixel area array detector operating in 
700-850 nm spectral range. It has an F/4 optical system with $35 \mathrm{~mm}$ focal length. The acquired data can be stored in $2 \mathrm{~Gb}$ Triple modular redundant memory.

\begin{tabular}{|c|c|c|}
\hline \multicolumn{2}{|c|}{ TABLE IV. } & SALIENT FEATURES OF JUGNU \\
\hline Sl.No & Parameter & Value/System \\
\hline 1 & Payload & $\begin{array}{l}\text { Near IR Camera } \\
640 \text { x } 480 \text { pixel Image } \\
197 \text { m resolution }\end{array}$ \\
\hline 2 & Mass(kg) & 3 \\
\hline 3 & Size $\left(\mathrm{mm}^{3}\right)$ & $10 \times 10 \times 34 \mathrm{~cm}^{3}$ \\
\hline 4 & Power $(\mathrm{W})$ & Solar cells, batteries \\
\hline 5 & Attitude sensor & MEMS based IMU \\
\hline 6 & Actuators & \\
\hline 7 & Stabilization & 3 axis stabilisation \\
\hline 8 & OBC & --- \\
\hline 9 & $\begin{array}{l}\text { TC Uplink } \\
\text { TM Downlink } \\
\text { Beacon }\end{array}$ & $\begin{array}{l}145.980 \mathrm{MHz} \\
437.505 \mathrm{MHz} \\
437.275 \mathrm{MHz}\end{array}$ \\
\hline 10 & Orbit & Near Equatorial orbit \\
\hline 11 & Altitude $(\mathrm{km}$ & $850 \mathrm{~km} \times 866 \mathrm{~km}$ \\
\hline 12 & Local time & NA \\
\hline 13 & Orbital Period & $\sim 102 \mathrm{~min}$ \\
\hline 14 & Inclination & $19.9^{\circ}$ \\
\hline 15 & Launch Date & $12^{\text {th }}$ October 2011 \\
\hline 16 & Launch vehicle & PSLV-C18 \\
\hline
\end{tabular}

\section{Ground Station}

A ground station for monitoring and control has been established in IIT Kanpur. It consists of Yagi-Uda antenna for uplink and down link, GUI interface in Lab VIEW and rotary system.

\section{SRMSAT}

SRMSAT was designed and developed by the students of Sri Ramasamy Memorial (SRM) University, Kattankulathur, Kanchepuram district. The view and salient features of the satellite are provided in Fig.-5 and Table-5 respectively.

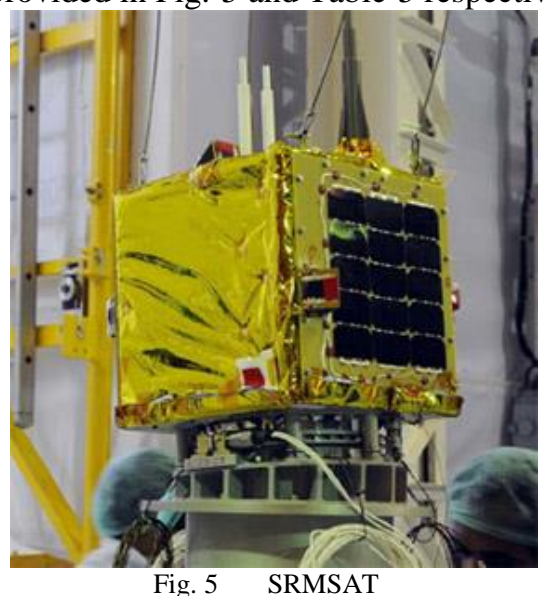

\section{Objective}

- To monitor green house gases in Near Infrared region $900 \mathrm{~nm}-1700 \mathrm{~nm}$.

\section{Payload}

SRMSAT Payload is a grating spectrometer for monitoring Earth-based sources and sinks of anthropogenic and natural sources of greenhouse gases.

\begin{tabular}{|l|l|l|}
\multicolumn{3}{|c}{ TABLE V. SALIENT FEATURES OF SRMSAT } \\
\hline Sl.No & Parameter & Value/ System \\
\hline 1 & Payload & $\begin{array}{l}\text { Near IR Camera } \\
640 \times 480 \text { pixel Image } \\
161 \text { m resolution }\end{array}$ \\
\hline 2 & & 3 \\
\hline 3 & Sass $(\mathrm{kg})$ & $10 \times 10 \times 34 \mathrm{~cm}^{3}$ \\
\hline 4 & Power $(\mathrm{W})$ & Solar cells, batteries \\
\hline 5 & Attitude sensor & IMU \\
\hline 6 & Actuators & Magnetic Torquer \\
\hline 7 & Stabilization & 3 axis stabilisation \\
\hline 8 & OBC & --- \\
\hline 9 & TCUplink & $437.505 \mathrm{MHz}(\mathrm{UHF})$ \\
& TM Downlink & $145.98 \mathrm{MHz}(\mathrm{VHF})$ \\
\hline 10 & Orbit & SSPO \\
\hline 11 & Altitude $(\mathrm{km})$ & $860 \mathrm{~km}$ \\
\hline 12 & Local time & 9.30 AM \\
\hline 13 & Orbital Period & 102 min \\
\hline 14 & Inclination & $19.9{ }^{\circ}$ \\
\hline 15 & Launch Date & $12^{\text {th }}$ October 2011 \\
\hline 16 & Launch vehicle & PSLV-C18 \\
\hline
\end{tabular}

\section{Ground Station}

The SRMSAT team setup aground station at the SRM University Kattankulathur campus and tracked the satellite

\section{SWAYAM}

Swayam a passive stabilization communication Satellite was developed by undergraduate students of College of Engineering, Pune. The payload flown on this satellite is to support point to point communication[6]. User can send and receive messages from one point to other point on the earth. The view and salient features of the satellite are provided in Fig. 6 and Table-6 respectively.

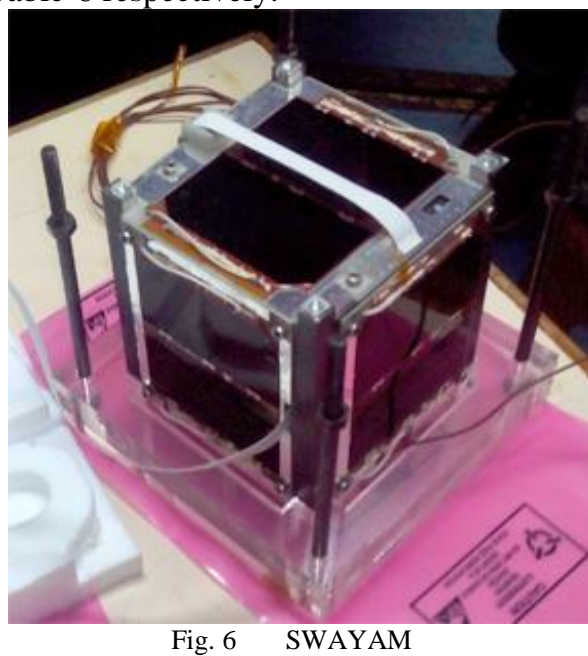

Objective

- To demonstrate passive attitude control.

To provide point to point messaging services to the HAM Community using a bidirectional communication satellite.

UHF channel performance evaluation develop a bidirectional communication satellite.

\section{Payload}

The payload was designed to support message store and forward. 


\begin{tabular}{|c|c|c|}
\hline \multicolumn{2}{|c|}{ TABLE VI. } & SALIENT FEATURES OF SWAYAM \\
\hline S1.No & Parameter & Value/System \\
\hline 1 & Payload & Store and Forward Messaging \\
\hline 2 & Mass $(\mathrm{kg})$ & $990 \mathrm{~g}$. \\
\hline 3 & Size $\left(\mathrm{mm}^{3}\right)$ & $10 \times 10 \times 11.35 \mathrm{~cm}$ \\
\hline 4 & Power $(\mathrm{W})$ & 3.3 Solar Cells Batteries \\
\hline 5 & Attitude sensor & \\
\hline 6 & Actuators & $\begin{array}{l}\text { Magnetic } \\
\text { gyroscope }\end{array}$ torque $\quad$ MEMS \\
\hline 7 & Stabilization & 3 axis stabilisation \\
\hline 8 & $\mathrm{OBC}$ & --- \\
\hline 9 & $\begin{array}{l}\text { TT Uplink } \\
\text { TM Downlink }\end{array}$ & $437.025 \mathrm{MHz}$ \\
\hline 10 & Orbit & SSPO \\
\hline 11 & Altitude $(\mathrm{km})$ & 515 \\
\hline 12 & Local time & $9.30 \mathrm{AM}$ \\
\hline 13 & Orbital Period & $94.5 \mathrm{~min}$ \\
\hline 14 & Inclination & $97.3 \mathrm{deg}$ \\
\hline 15 & Launch Date & 22nd June, 2016 \\
\hline 16 & Launch vehicle & PSLV-C34 \\
\hline
\end{tabular}

\section{SATYABAMASAT}

The satyabamasatellite was designed and fabricated by the students of Sathyabama university, Chennai to measure the concentration of green house effect gases [7]. The satellite is shown in Fig.7 and the salient feature of the satellite are provided in Table-7

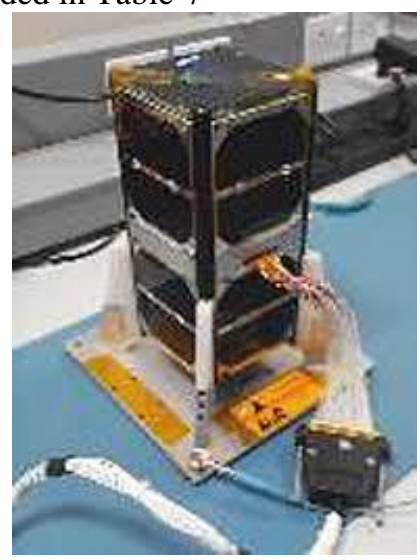

Fig. 7 SathyabamaSat

\section{Objective}

- To maximize the learning experience of the students

- To provide a real-time design and development experience for the students on compact space systems.

- To monitor the concentration of green house gases present in the atmosphere.

- To obtain the pollution model for India through the data collected using spectrometer payload.

- To interpret the acquired data and represent the concentration of greenhouse gases in PPM.

\section{Payload}

It is an imaging camera (ARGUS 1000) operated in Infrared spectral region. The payload is operated only over the regions where the experimentations are interested, and it delivers the data to the On-Board Computer (OBC) for transmission, when it crosses the radio window of ground station, which is being built in Sathyabama University campus, Chennai, India.

\begin{tabular}{|c|c|c|}
\hline ABLE VII. & \multicolumn{2}{|c|}{ SALIENT FEATURES OF SATHYABAMA SATELLITE } \\
\hline Sl.No & Parameter & Value/System \\
\hline 1 & Payload & $\begin{array}{l}\text { Imaging satellite to detect } \\
\text { green house gases. (Argus } \\
1000 \text { ) }\end{array}$ \\
\hline 2 & Mass(kg) & $1.779(2 \mathrm{U})$ \\
\hline 3 & Size $\left(\mathrm{mm}^{3}\right)$ & $10 \times 10 \times 22 \mathrm{~cm}$ \\
\hline 4 & Power $(\mathrm{W})$ & 3.6 \\
\hline 5 & Attitude sensor & Sun sensor \\
\hline 6 & Actuators & Magnetic torquer \\
\hline 7 & Stabilization & 3 axis stabilized \\
\hline 8 & $\mathrm{OBC}$ & ARM 7 Based \\
\hline 9 & $\begin{array}{l}\text { TT Uplink } \\
\text { TM Downlink } \\
\text { BEACON }\end{array}$ & $\begin{array}{l}437.980 \mathrm{MHz} \\
145.980 \mathrm{MHz} \\
145.980 \mathrm{MHz}\end{array}$ \\
\hline 10 & Orbit & SSPO \\
\hline 11 & Altitude $(\mathrm{km})$ & 505 \\
\hline 12 & Local time & $9.30 \mathrm{AM}$ \\
\hline 13 & Orbital Period & $94.5 \mathrm{~min}$ \\
\hline 14 & Inclination & 97.3 Deg \\
\hline 15 & Launch Date & 22nd June, 2016 \\
\hline 16 & Launch vehicle & PSLV-C34 \\
\hline
\end{tabular}

\section{Ground Station}

Ground station is established in Sathyabama university, Chennai.

\section{PISAT}

PISAT was designed and fabricated by a consortium of Indian colleges led by PES University, with the support of ISRO (Indian Space Research Organization) and IE (Institution of Engineers) of India to provide a hands-on environment for students in all aspects of satellite building and operations[8].

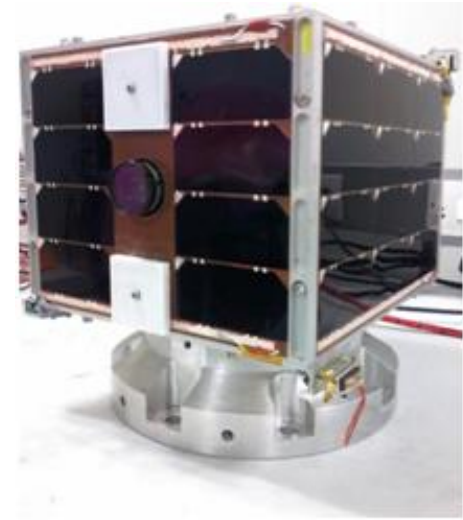

Fig. 8 PISAT

\section{Objective}

- To develop, design a space system in university environment with our students and young faculty.

Payload

The PISAT payload is a 166 gm CMOS based camera with 10-bit radiometric resolution. It has an area array detector with $2048 \mathrm{H}$ x $1536 \mathrm{~V}$ pixels. This covers $185 \mathrm{~km} \mathrm{x}$ $135 \mathrm{~km}$ area with $90 \mathrm{~m}$ spatial resolution.

\begin{tabular}{|l|l|lll|}
\hline TABLE VIII. & SALIENT FEATURES OF PISAT \\
\hline 1 & Parameter & Value/System & & \\
\hline 2 & Payload & Imaging camera & & \\
\hline 3 & Mass $(\mathrm{kg})$ & 5.3 & & \\
\hline 4 & Size $\left(\mathrm{mm}^{3}\right)$ & $254 \times 256 \times 181$ & & \\
& Power $(\mathrm{W})$ & $13 \mathrm{~W}$ in sunlit & & \\
\hline 5 & & 5.2 Ahr Battery & & \\
\hline
\end{tabular}




\begin{tabular}{|l|l|l|}
\hline S1.No & Parameter & Value/System \\
\hline & & $\begin{array}{l}\text { (Inertial Measurement Unit) and } \\
\text { FPSS }\end{array}$ \\
\hline 6 & Actuators & Magnetic Torque Rods \\
\hline 7 & Stabilization & Three axis stabilisation \\
\hline 8 & OBC & $\begin{array}{l}\text { Based on AVR32- AT32UC3A0512 } \\
\text { micro controller. Pointing accuracy } \\
5 \text { deg. }\end{array}$ \\
\hline 9 & TCUplink & $\begin{array}{l}2030 \mathrm{MHz} \\
2240 \mathrm{MHz}\end{array}$ \\
\hline 10 & OM Downlink & SSPO \\
\hline 11 & Altitude (km) & 690 \\
\hline 12 & Local time & 11.30 AM \\
\hline 13 & Orbital Period & 98.4 min \\
\hline 14 & Inclination & 98 deg \\
\hline 15 & Launch Date & $26^{\text {th }}$ Sept 2016 \\
\hline 16 & Launch vehicle & PSLVC35 \\
\hline
\end{tabular}

Ground station

PISAT team has developed a ground station with $3 / 7 \mathrm{~m}$ paraboloid antenna with prime focus.

\section{PRATHAM}

This satellite was designed and fabricated by Indian Institute of Technology (IIT) Bombay Students[9,10].

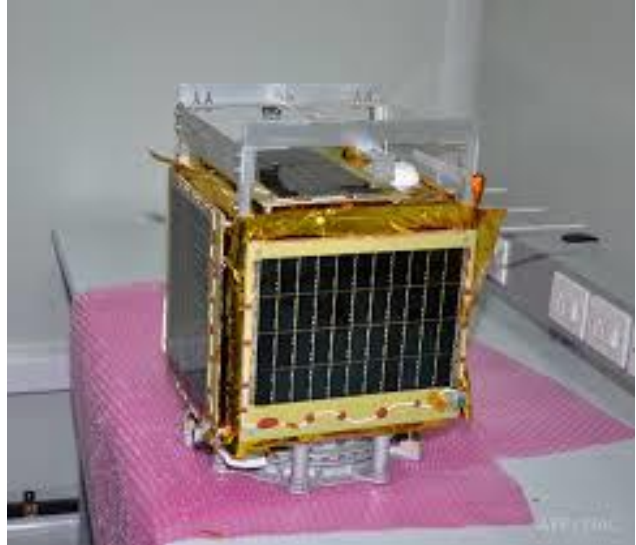

Fig. 9 PRATHAM

\section{Objective}

- To enable students and faculty to gain knowledge and experience in the field of Satellite and Space Technology.

- To empower the Satellite Team with the skills to develop the Satellite through various phases of Design, Analysis, Fabrication and Testing until the Flight Model is made.

- To launch the satellite into orbit and measuring Total Electron Count of the Ionosphere.

- To involve students from other universities in our Satellite mission by building ground stations in their universities.

\section{Payload}

The PRATHAM Payload is designed to derive the total electron count in the ionosphere.

TABLE IX. SALIENT FEATURES OF PRATHAM

\begin{tabular}{|l|l|l|}
\hline Sl.No & Parameter & Value/System \\
\hline 1 & Payload & $\begin{array}{l}\text { Total Electron Count (TEC) in } \\
\text { ionosphere }\end{array}$ \\
\hline 2 & Mass $(\mathrm{kg})$ & 10 \\
\hline 3 & Size $\left(\mathrm{mm}^{3}\right)$ & $30.5 \times 33.5 \times 46.6 \mathrm{~cm}^{3}$ \\
\hline 4 & Power $(\mathrm{W})$ & $13 \mathrm{~W} 6.6$ Ahr Battery \\
\hline 5 & Attitude sensor & $\begin{array}{l}\text { Sun sensor } \\
\text { Magnetometer }\end{array}$ \\
\hline
\end{tabular}

\begin{tabular}{|l|l|l|}
\hline 6 & Actuators & Magnetic Torquer \\
\hline 7 & Stabilization & 3 Axis stabilised \\
\hline 8 & OBC & --- \\
\hline 9 & TCUplink & No uplink \\
& TM Downlink & $437 \mathrm{MHz}$ \\
& Beacon & $145.98 \mathrm{MHz}$ \\
\hline 10 & Orbit & SSPO \\
\hline 11 & Altitude $(\mathrm{km})$ & 670 \\
\hline 12 & Local time & $1.30 \mathrm{AM}$ \\
\hline 13 & Orbital Period & $98.4 \mathrm{~min}$ \\
\hline 14 & Inclination & 98 deg \\
\hline 15 & Launch Date & $26^{\text {th }}$ Sept 2016 \\
\hline 16 & Launch vehicle & PSLV- C35 \\
\hline
\end{tabular}

\section{Ground Station}

Separate ground station is established at roof top of Aerospace department. in IIT Mumbai. Atharva college of engineering also established a ground station for Pratham One ground station was setup in France by French students to receive data from Pratham.

\section{NIUSAT}

This satellite was designed and fabricated by Noorul Islam University, thuckalay, Kumarakoil, Tamilnadu[11].

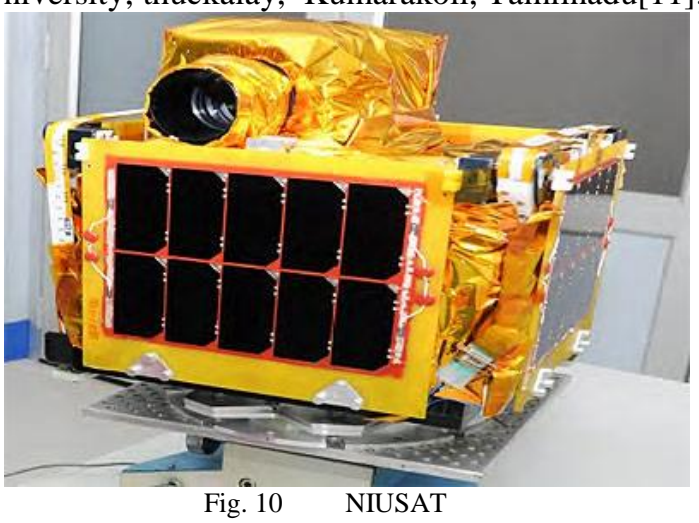

Objective

- To enable new entrants in the industry/next generation students and aerospace aspirants.

Payload

The NIUSAT payload is a four spectral band wide field Sensor. It covers $50 \times 50 \mathrm{~km}$ and $25 \mathrm{~m}$ resolution from the altitude of $\sim 500 \mathrm{~km}$

\begin{tabular}{|c|c|c|}
\hline Sl.No & Parameter & Value/System \\
\hline 1 & Payload & Imaging camera \\
\hline 2 & Mass(kg) & 15 \\
\hline 3 & Size $\left(\mathrm{mm}^{3}\right)$ & $274 \times 274 \times 195$ \\
\hline 4 & Power $(\mathrm{W})$ & $\begin{array}{l}\text { Deployable solar panels } \\
\text { multi junction solar } \\
\text { generates } 40 \mathrm{~W} \text { in sunlit. }\end{array}$ \\
\hline 5 & Attitude sensor & $\begin{array}{l}\text { Sun sensors magnetometers, } \\
\begin{array}{l}\text { MEMS gyroscopes and star } \\
\text { tracker }\end{array}\end{array}$ \\
\hline 6 & Actuators & $\begin{array}{l}\text { Miniature Reaction Wheels and } \\
\text { Magnetic torquers }\end{array}$ \\
\hline 7 & Stabilization & 3 axis stabilisation \\
\hline 8 & $\mathrm{OBC}$ & --- \\
\hline 9 & $\begin{array}{l}\text { TC Uplink } \\
\text { TM Downlink } \\
\text { Payload data } \\
\end{array}$ & $\begin{array}{l}144-148 \mathrm{MHz} \\
420-450 \mathrm{MHz} \\
2240 \mathrm{MHz}(\mathrm{S}-\mathrm{Band})\end{array}$ \\
\hline 10 & Orbit & SSPO \\
\hline 11 & Altitude $(\mathrm{km})$ & $496 \times 517$ \\
\hline 12 & Local time & $9.30 \mathrm{AM}$ \\
\hline
\end{tabular}




\begin{tabular}{|l|l|l|}
\hline Sl.No & Parameter & Value/System \\
\hline 13 & Orbital Period & $93 \mathrm{~min}$ \\
\hline 14 & Inclination & $97.45 \mathrm{deg}$. \\
\hline 15 & Launch Date & $23^{\text {rd }}$ June, 2017 \\
\hline 16 & Launch vehicle & PSLV- C34 \\
\hline
\end{tabular}

\section{Ground station}

The NIUSAT ground station consists of mission control centre and Payload data processing centre. It has a three meter antenna which supports UHF downlink and VHF Uplink.

\section{KALAMSAT-V2}

The KalamsatV2, payload named after former Indian president APJ Abdul Kalam is the first to use the fourth stage of PSLV as an orbital platform. 24 ${ }^{\text {th }}$ January 2019. This payload was developed by students and Chennai-based Space Kidz India. The satellite is the smallest weighing $1.2 \mathrm{~kg}$ and has a lifespan of two months.

\section{SATELLITES UNDER DEVELOPMENT(MOU WITH ISRO)}

\section{PARIKSHIT}

Parikshit is being developed by Manipal Institute of technology, Manipal, Karnataka. MOU is signed with ISRO for the launch of this satellite[12].

\section{IITMSAT}

IITMSAT is being developed by students of Indian Institute of Technology (IIT) Madras [13-16].

\section{Objective}

- The objective is to study the precipitation of high energy electrons and protons from VanAllen radiation belts to lower altitude of 600-900 $\mathrm{km}$ due to resonance interaction with low frequency EM waves.

\section{Payload}

IITMSAT will carry Space based Proton Electron Energy Detector (SPEED) instrument as payload to measure proton and electron fluxes in the Earth's magnetosphere.

\section{CONTINUATION SATELLITES PROJECTS}

Some educational institutions are proposing to launch satellites. Satellites and the Institutions are listed in Table-11 TABLE XI. CONTINUATION SATELLITE PROJECTS

\begin{tabular}{|l|l|}
\hline Satellite & Institution \\
\hline STUDSAT-2 & Nitte Meenakshi college \\
\hline PISAT-2 & PES institute of Technology \\
\hline SRMSAT-2 & SRM University \\
\hline
\end{tabular}

\section{STUDSAT-2}

The studsat-2 project is proposed with two nanosatellites to prove the capability of nanosatellites in docking experiment in space[17-18].

\section{PISAT-2}

PISAT-2 is proposed with imager which may point towards space for the study on stars.

\section{SRMSAT-2}

SRMSAT-2 is proposed to reach moon and have a study on the moon surface[19].

\section{SATELLITES LAUNCHED BY OTHER AGENCIES}

\section{KALAMSAT}

The Kalamsat, named after former Indian President Abdul Kalam, weighing 64 grams was designed and developed by 18 -year old Tamil Nadu student and his team. This satellite is $3.8 \mathrm{~cm}$ cube with $3-\mathrm{D}$ printed reinforced carbon fiber structure. The instrument carried by this satellite was Geiger Muller counter. This satellite was launched by NASA's sounding Rocket in June 2017. Sub-orbital spaceflights technically enter space, but do not get into orbit.

\section{INSTITUTIONS INVOLVED IN SPACE STUDIES}

Many Indian Institutes of Technologies have involved in space related studies through their various departments.

Indian institute of space science and technology (IIST) which is under Indian Space research Organization is carrying out many space related research in collaboration with other universities in India and abroad. Mainly it focuses in developing new technologies required for future satellites and launch vehicles.

\section{SATELLITES LAUNCHED WITH BALLOONS}

Many colleges have started the satellite systems study and testing their systems by launching them using balloons. Some colleges are mentioned below as samples.

\section{PERIYAR MANIAMMAI INSTITUTE OF SCIENCE TECHNOLOGY (DEEMED TO BE UNIVERSITY)}

A team of girls of Periyar Maniammai Institute of Science Technology (Deemed to be University), Vallam, launched a satellite using helium-filled balloon. The satellite was capable of sending live telemetry consisting of data and flight parameters to the control station at PMIST premises.

\section{VELLORE INSTITUTE OF TECHNOLOGY(VIT)}

Twelve payloads with satellite bus were launched using a helium-filled balloon by school students during the National Space Challenge-2020 (NNSC)from Vellore Institute of Technology(VIT). The balloon was expected to reach an altitude of 20 kilometers.

\section{CONCLUSION}

The Indian Space Research Organisation (ISRO) has created Space systems awareness among Indian Students and helped in design, fabrication, testing and launch of satellites developed by Indian students. Now many colleges continuing the space study autonomously.

\section{ACKNOWLEDGEMENT}

The author wish to acknowledge the Director U.R Rao Satellite Centre, Bangalore and the Programme Director, IRS \& SSS programme for their continuous support and encouragement.

\section{REFERENCES}

[1] Neetu Sharma, Satish K Jain, S.V.Charhate, "Trend of Very Small Satellites Design and Development in Indian Prospective", Conference by Antenna Test \& Measurement Society

[2] R.Dhanraj, Mala John, P.V.Ramakrishna, B.Umamaheshwari and V.Vaidehi, "Design, Development and Two Years of On Orbit Operation of ANUSAT" Paper presented at the Natioanl conference 
on Space Transportation systems STS 201 held at VSSC, ISRO Trivandrum 16th to 18 thDec 2011

[3] K. Thyagarajan, J.P.Gupta, P.S.Goel and Prof K. Jayaraman “, University Small Satellite Program - ANUSAT" ISRO Satellite Centre, Bangalore - India.

[4] C.Angadi, ZManjiyani, C. Dixit, K.vigneshwaran, G.S.Avinash, P.R.Narendra, S. Prasad, H. Ramavaram, R.M.Mamatha, G.Karthik, H.V.Arpan, A.H.Sharath. P.S. Kiran and K.Visweswaran. “ STUDSAT: India's first student Pico Satellite project" Aerospace Conference, pp. 1-15, 2011.

[5] Mayank singh,Rohit Singla,Sushant Rajliwa ,"JUGNU for Carbon Check" International journal for research in applied science and Engineering technology (IJRASET), comVol.2Issue IX, 2014.

[6] S.Kulkarni, S.Bangade, N. Sambhus, M.Khadse, D.Waghule, P.Aher, K.Gaikwad and S. Thakurdesai." Design and optimization of the onboard DC/DC converters of swayam satellite." IEEE International Conference on Power Electronics, Drives and Energy Systems (PEDES), pp1-6. 2015.

[7] B.Sheela Rani, .R.Santhosh, LeniSam Prabhu, Michel Federick, Vipin Kumar and Sai santhosh, "A survey to select microcontroller for Sathyabama satellite's Onboard Computer subsystem," in proceeding of the international conference, Recent Advances in Space Technology Services and Climate change (RSTSCC), 2010.

[8] Gaurav Agarwal, Ajay Kumar, Mahendra M Nayak and Dr. V K Agarwal "Design of a Student Satellite- PISAT", Volume26, Issues1APCOSEC 2016 9-11 Nov, Bangalore, India

[9] Pratham, IIT Bombay Student Satellite Project Website: www.aero.iitb.ac.in/pratham.

[10] Sanyam S. Mulay, Jaideep Joshi, Yashovardhan S. Chati, Vaibhav V. Unhelkar, Saptarshi Bandyopadhyaył Shashank Tamaskar, Mallesh Bommanahal, Chaitanya Talnikar, Avnish Kumar and Hari B. Hablani," Attitude Determination And Control of Pratham, Indian Institute Of Technology Bombay's First Student Satellite“, IAA-AASDyCoSS1-13-11.

[11] Shajin Nargunam A. Marappa Krishnaswamy "Nano Satellite Based Environmental Monitoring" 65th International Astronautical Congress 2014.

[12] Naman Vaidya, Aditya Shanker, Ankit Agarwal, Ananya Pramanik, Chandrasekhar Nagarajan Ankur Dev, Thomas John, "Small and Very Small Advanced Space Power Systems" IAC-13,C3,4,x19937 64th International Astronautical Congress2013.

[13] D.Kannapan, A. Gulati, G. Saha, and S. Kumar, "Design of the attitude control subsystem of IITMSAT,Ageomagnetic field pointing satellite," Proc. of 24th AAS/AIAA Space Flight Mechanics Meeting, 2014.

[14] Sooraj Gopakumar, Saisree Eega, Susurla V S Suresh, Madadi Sai Sriram Reddy, Anand Antony, Harishankar Ramachandran and David Koilpillai." Design of Electrical Power Subsystem for IITMSAT" International Conference on Space Science and Communication (IconSpace) held at Langkawi, Malaysia, 2015.

[15] Akshay Gulati, Shubham Chavan, Joseph Samuel, Sampoornam Srinivasan, Pradeep Shekhar, Akshat Dave, Aditya Sant, Sourbh Bhadane, Mayug Maniparambil, Vishnu Prasad Sivasankarakurup, Dhanalakshmi Durairaj, David Koilpillai, Harishankar Ramachandran, "IITMSAT Communications System : A LeanSat Design Approach" The 3rd IAA Conference On University Satellite Missions. December 2015.

[16] A.Gulati, N.Sivadas, D.Kannapan, H. D.Koilpillai, S.Ansari, A.Gaurav, J.Mohanbai, N.Chandrachoodan, and R.Talashila, "An efficient nanosatellite for a large payload," Proc. of 5th nanosatellite symposium, 2013.

[17] Sandesh R Hegde, DivyanshuSahay,SSandya, Sandeep G M, Muralidhara, Nikhilesh K V Nitte Mahalinga Adyanthaya "Design and Development of Inter-Satellite Separation Mechanism for Twin Nano Satellite-STUDSAT-2"

[18] S. Nagabhushana, S.Dasiga, Loganathan.M, B.Rajulu and M.Divya," Orbital analysis and hardware configuration for InterSatellite Link in STUDSAT-2," IEEE Aerospace Conference, pp 1-6., 2014.

[19] AkashRatheesh et.al," SRMSAT: A Feasibility Study on Small Satellite Mission to Moon", 54th AIAA Aerospace Sciences Meeting, AIAA SciTech 2016 San Diego, CA. 